\title{
Identification of Small Grains Genotypes Resistant to Soilborne wheat mosaic virus
}

L. Cadle-Davidson, Department of Plant Pathology, M. E. Sorrells, Department of Plant Breeding and Genetics, S. M. Gray, United States Department of Agriculture-Agricultural Research Service (USDA-ARS), Plant Protection Research Unit, and G. C. Bergstrom, Department of Plant Pathology, Cornell University, Ithaca, NY 14853

\begin{abstract}
Cadle-Davidson, L., Sorrells, M. E., Gray, S. M., and Bergstrom, G. C. 2006. Identification of small grains genotypes resistant to Soilborne wheat mosaic virus. Plant Dis. 90:1039-1044.

Soilborne wheat mosaic virus (SBWMV) was detected in New York in 1998 for the first time and has been associated with yield loss where identified. We assessed 115 regionally adapted small grains genotypes for resistance to SBWMV over four growing seasons. Resistance to SBWMV reduces the percentage of plants that develop detectable viral titer and symptoms. Logistic regression was used to analyze disease incidence data and was compared with a general linear model for categorizing relative resistance to SBWMV. Logistic regression facilitated assessment of the effects of small sample size, low disease incidence, and nonuniform disease distribution. By increasing sample size from 20 to 30 stems per replicate, the number of resistance categories was increased through improved resolution of intermediate resistance classes. In environments with low disease incidence, the number of genotypes categorized as susceptible decreased while intermediate genotypes appeared to be resistant in the analysis. Inclusion of disease distribution data as covariates in a spatially balanced experiment did not increase the power of the logistic analysis. No genotype assessed in multiple years was immune to infection. However, 41 of the regionally adapted genotypes tested repeatedly expressed strong resistance to SBWMV, providing growers a choice of cultivars resistant to SBWMV.
\end{abstract}

Soilborne wheat mosaic virus (SBWMV) infects wheat, rye, triticale, and barley, causing disease and yield loss on those crops sown in the autumn $(12,13)$. SBWMV first was detected in New York State in 1998 and since then has been spreading in the Finger Lakes region, where autumn-sown small grains are important in crop rotations with vegetables and other field crops. Prior to 1998, small grains bred in New York State did not undergo testing for resistance to SBWMV.

In New York, SBWMV symptom expression begins in late April, with typical chlorotic symptoms appearing in patches of plants where machinery first entered the field, reflecting recent introduction of the virus. Symptoms on individual leaves are a genotype-specific mosaic $(13,21)$. Symptoms fail to develop on emerging leaves when the average temperature exceeds $20^{\circ} \mathrm{C}$ (11), but can reinitiate on new growth as flag leaves emerge given conducive weather conditions (L. Cadle-

Corresponding author: G. C. Bergstrom

E-mail: gcb3@ cornell.edu

Current address of L. Cadle-Davidson: USDAARS, Grape Genetics Research Unit, Cornell University, Geneva, NY 14456.

Accepted for publication 13 March 2006.

\section{DOI: 10.1094/PD-90-1039}

This article is in the public domain and not copyrightable. It may be freely reprinted with customary crediting of the source. The American Phytopathological Society, 2006.
Davidson and G. C. Bergstrom, unpublished). Wet autumns and prolonged cool periods in spring are conducive for disease development.

SBWMV presumably is vectored by the protozoan plasmodiophorid Polymyxa graminis, an obligate parasite of wheat roots that can survive in dry soil without a host for at least 10 years while retaining transmissibility of the viruses it may harbor (1). A controlled environment study using infested field soil suggested that optimal SBWMV transmission requires at least $24 \mathrm{~h}$ of matric potentials greater than $-20 \mathrm{kPa}$ (wetter than field capacity) any time after seedling emergence but before soil temperatures drop below $7^{\circ} \mathrm{C}$ (7). Suboptimal soil temperature or moisture in the autumn results in less efficient transmission and, therefore, reduced disease incidence the following spring (6). Furthermore, cool weather in the spring promotes the development and maintenance of symptoms and disease severity.

Currently, the only feasible control tactic for SBWMV, once inoculum has become established in a field, is the planting of resistant cultivars (11). Resistance to SBWMV appears to be controlled by one to three genes $(4,14,15,17,18,20)$. Resistance most often is expressed as a reduction in the incidence of symptomatic plants, but not necessarily as reduced titer or severity in infected plants $(5,10,16,19)$. Because cultivar resistance against the putative vector has not been identified $(2,3,22)$, SBWMV is likely to be transmitted to the cortical root tissue of most host genotypes. Therefore, the resistance observed involves the inability of SBWMV to move from colonized roots to foliar tissue and result in symptoms (16). Resistance evaluation using mechanical inoculation of leaves does not translate to field resistance, because resistance appears to be directed against root-to-shoot movement and not systemic movement in the shoots (16).

In this study, we evaluated host resistance to SBWMV in 115 wheat, rye, triticale, and barley genotypes based on incidence data. Additionally, we identified the effects of spatial heterogeneity, small sample sizes, and low disease pressure on resistance evaluation, and an experimental design was suggested to overcome these potential problems.

\section{MATERIALS AND METHODS}

Plant materials. The genotypes included in this study composed two sets selected for evaluation by the small grains breeding program at Cornell University, Ithaca, NY. One set included only soft white winter wheat (SWWW) genotypes, the majority being advanced breeding lines. The other set was predominantly soft red winter wheat (SRWW) cultivars, but included several barley, rye, triticale, and SWWW cultivars. In 1999 to 2000, our nursery included the two sets of 40 genotypes, including several genotypes that were included in both sets. In subsequent years, we added genotypes of interest. By the end of the study, we had evaluated 115 genotypes.

Field evaluation. The SWWW and SRWW genotypes were planted in a grower's field nursery in Trumansburg, NY (Conesus gravelly silt loam soil) as two separate experiments in a randomized complete block design with three replications of single $1-\mathrm{m}$ rows with seed planted at $5 \mathrm{~g} / \mathrm{m}$. In 2001-02, limited resources reduced the sample size to 20 stems from each of the two replicate blocks with the highest disease incidence. The SBWMV nursery in Trumansburg was planted to susceptible winter wheat continuously from 1997 to 2002 and expressed consistent natural occurrence of SBWM symptoms every year. In the last two growing seasons of the study (2001-02 and 200203), the locations of the blocks were dispersed in a spatially balanced, nonrandom design in order to increase the likelihood that both nurseries encountered strong disease pressure. 
Each year the SBWMV nursery was plowed, disked, and harrowed, incorporating 10-20-20 NPK at $225 \mathrm{~kg} \mathrm{ha}^{-1}$ prior to September planting. In early May, during peak symptom expression, stems were harvested from a majority of plants in each row. Thirty stems were subsampled arbitrarily and rated individually for expression of viral symptoms in a laboratory setting. In the first year of the study, visual assessment was verified using enzymelinked immunosorbent assay (ELISA) to detect SBWMV coat protein as per the manufacturer's instructions (Agdia, Elkhart, IN). Sap for ELISA was extracted from roots of individual plants using a rolling leaf press and diluted in $0.5 \mathrm{ml}$ of phosphate-buffered saline (PBS). Samples with absorbance values greater than five times the uninfected control were considered to be positive for SBWMV.

Disease incidence and distribution. The first 2 years of resistance assessments suggested that disease pressure was not distributed uniformly across the SBWMV nursery. To verify this observation, we planted the susceptible wheat cv. Harus in every sixth row in each of the last 2 years. Using the incidence of soilborne wheat mosaic (SBWM) disease on Harus, we then developed a disease incidence map across the field for each of the last 2 years using a geographic information system (ArcGIS; ESRI, Redlands, CA). The midpoint of each row was assigned a point location along with the corresponding SBWM incidence. A Kriging analysis was used for interpolating between Harus rows (9). The resulting surface was intended to be diagnostic and to suggest whether the statistical analyses ought to take disease gradients into account.

Statistical analysis. The logistic analysis and visual representation as described by Cadle-Davidson et al. (8) was used to define resistance classes and assign genotypes to them. Criteria for delineating relative resistance categories can be devised based on the end use; however, in this article, "discrete resistance classes" were used to compare objectively the power of each analysis. For identifying the maximal number of discrete resistance classes, the interval that included the most susceptible genotype based on disease incidence was used as the first class. The next most susceptible genotype that had significantly lower percent incidence than the first genotype (non-overlapping bars) then was identified. This defined the second class, and the process was continued until no genotypes had significantly lower percent incidence than the previous genotype.

\section{RESULTS}

Disease incidence and distribution. The average percent incidence of SBWM over 4 years ranged from 0 to $83 \%$ for individual genotypes, with the average incidence of all genotypes being $16.6 \%$
Table 1. Four-year summary statistics for percent incidence of Soilborne wheat mosaic virus (SBWM) for each genotype tested

\begin{tabular}{|c|c|c|c|c|c|}
\hline Cultivar & $\begin{array}{c}\text { Average } \\
(\%)^{\mathrm{a}}\end{array}$ & $\begin{array}{l}\text { Min } \\
(\%)^{b}\end{array}$ & $\begin{array}{l}\operatorname{Max} \\
(\%)^{c}\end{array}$ & $\begin{array}{l}\text { Sampled } \\
\text { rows }^{\mathrm{d}}\end{array}$ & $\begin{array}{c}\text { Years } \\
\text { tested }^{\mathrm{e}}\end{array}$ \\
\hline NY89088-8152 & 83.0 & 63.3 & 90.0 & 5 & 3,4 \\
\hline NY89088-8173 & 71.7 & 10.0 & 95.0 & 7 & 3,4 \\
\hline NY88046-8138 & 69.7 & 23.3 & 100.0 & 5 & 3,4 \\
\hline NY87048W-7388 & 68.7 & 20.0 & 95.0 & 5 & 3,4 \\
\hline NY89088-7401 & 68.3 & 43.3 & 95.0 & 5 & 3,4 \\
\hline NY89088-9118 & 61.1 & 60.0 & 63.3 & 3 & 4 \\
\hline VA98W-593 & 59.7 & 3.3 & 100.0 & 5 & 3,4 \\
\hline NY89035SP-8162 & 59.0 & 10.0 & 95.0 & 5 & 3,4 \\
\hline NY89063-9126 & 56.7 & 26.7 & 73.3 & 3 & 4 \\
\hline Genesis 9953 & 51.0 & 10.0 & 95.0 & 5 & 3,4 \\
\hline VA97W-375 & 49.7 & 16.7 & 90.0 & 5 & 3,4 \\
\hline Sisson & 49.1 & 10.0 & 95.0 & 11 & $1,2,3,4$ \\
\hline TW044-065 & 48.9 & 23.3 & 63.3 & 3 & 4 \\
\hline TW97613 & 48.3 & 10.0 & 100.0 & 11 & $1,2,3,4$ \\
\hline TW006-007 & 48.0 & 13.3 & 100.0 & 5 & 3,4 \\
\hline Va 96W-247 & 47.1 & 10.0 & 95.0 & 11 & $1,2,3,4$ \\
\hline CaledoniaResel-VT & 45.6 & 13.3 & 80.0 & 3 & 4 \\
\hline RSI111 & 45.3 & 0.0 & 90.0 & 5 & 3,4 \\
\hline Freedom & 42.7 & 0.0 & 100.0 & 11 & $1,2,3,4$ \\
\hline NY89088-9101 & 42.2 & 16.7 & 56.7 & 3 & 4 \\
\hline Trical 336 (triticale) & 39.8 & 13.3 & 60.0 & 8 & $2,3,4$ \\
\hline RSI AZ 1998 (triticale) & 39.4 & 13.3 & 80.0 & 8 & $2,3,4$ \\
\hline NY89065SP-8113 & 39.0 & 20.0 & 65.0 & 7 & 3,4 \\
\hline Harus & 36.7 & 0.0 & 100.0 & 30 & $1,2,3,4$ \\
\hline NY89025-9111W & 35.6 & 13.3 & 80.0 & 3 & 4 \\
\hline Pioneer 2548 & 34.6 & 0.0 & 80.0 & 8 & $2,3,4$ \\
\hline Cardinal & 34.4 & 0.0 & 95.0 & 11 & $1,2,3,4$ \\
\hline Watford & 33.6 & 0.0 & 90.0 & 11 & $1,2,3,4$ \\
\hline Aroostock (rye) & 31.5 & 0.0 & 90.0 & 8 & $2,3,4$ \\
\hline Marilee & 31.3 & 0.0 & 100.0 & 8 & $1,2,3$ \\
\hline Presto (triticale) & 30.0 & 0.0 & 80.0 & 11 & $1,2,3,4$ \\
\hline NY88045-8164 & 28.9 & 23.3 & 40.0 & 3 & 4 \\
\hline Mendon & 25.8 & 0.0 & 100.0 & 11 & $1,2,3,4$ \\
\hline Pioneer 25W33 & 25.5 & 0.0 & 80.0 & 11 & $1,2,3,4$ \\
\hline NY89078SP-8184 & 25.0 & 6.7 & 60.0 & 5 & 3,4 \\
\hline NY89073SP-8110 & 24.0 & 0.0 & 66.7 & 5 & 3,4 \\
\hline RSIBG 1998 (triticale) & 22.4 & 0.0 & 85.0 & 11 & $2,3,4$ \\
\hline CaledoniaResel-L & 20.0 & 3.3 & 40.0 & 3 & 4 \\
\hline Bobcat (triticale) & 15.6 & 0.0 & 43.3 & 3 & 4 \\
\hline Puma (rye) & 15.6 & 10.0 & 23.3 & 3 & 2 \\
\hline AC Ron & 13.9 & 0.0 & 46.7 & 11 & $1,2,3,4$ \\
\hline Pioneer 2540 & 13.9 & 0.0 & 100.0 & 11 & $1,2,3,4$ \\
\hline Va97W-375WS & 12.2 & 3.3 & 26.7 & 3 & 4 \\
\hline M98*2152 & 11.1 & 0.0 & 26.7 & 3 & 4 \\
\hline NY88048-8185 & 9.8 & 0.0 & 33.3 & 7 & 3,4 \\
\hline NY89073SP-8145 & 9.0 & 0.0 & 20.0 & 5 & 3,4 \\
\hline RSI 111 (triticale) & 8.9 & 3.3 & 13.3 & 3 & 2 \\
\hline Roane & 8.6 & 0.0 & 73.3 & 11 & $1,2,3,4$ \\
\hline Trical 815 (triticale) & 7.5 & 0.0 & 10.0 & 4 & $1,2,3$ \\
\hline NY89037SP-8140 & 7.0 & 0.0 & 30.0 & 5 & 3,4 \\
\hline NY88036-8082 & 6.7 & 0.0 & 26.7 & 7 & 3,4 \\
\hline OH 530 & 6.1 & 0.0 & 16.7 & 11 & $1,2,3,4$ \\
\hline D8006 & 6.0 & 0.0 & 20.0 & 5 & 2,3 \\
\hline NY89059SP-8094 & 5.7 & 0.0 & 13.3 & 5 & 3,4 \\
\hline NY91028-9073 & 5.6 & 0.0 & 13.3 & 3 & 4 \\
\hline VAN98W-170WS & 5.6 & 0.0 & 13.3 & 3 & 4 \\
\hline RSI815 & 4.8 & 0.0 & 15.0 & 9 & $1,2,3,4$ \\
\hline Pioneer 25R37 & 4.6 & 0.0 & 23.3 & 13 & $2,3,4$ \\
\hline CaledoniaResel-A & 4.4 & 0.0 & 6.7 & 3 & 4 \\
\hline CaledoniaResel-T & 4.4 & 0.0 & 10.0 & 3 & 4 \\
\hline Superior & 4.4 & 0.0 & 20.0 & 11 & $1,2,3,4$ \\
\hline McCormick & 4.3 & 0.0 & 10.0 & 5 & 3,4 \\
\hline NYBatavia & 4.2 & 0.0 & 16.7 & 11 & $1,2,3,4$ \\
\hline NY89086SP-9203 & 4.0 & 0.0 & 10.0 & 5 & 3,4 \\
\hline TW005-008 & 4.0 & 0.0 & 10.0 & 5 & 3,4 \\
\hline
\end{tabular}

a Average percent incidence: the sum of infected stems in all replications in all years tested divided by the total number of stems assessed.

${ }^{b}$ Minimum percentage of infected stems in any replication in any year.

${ }^{c}$ Maximum percentage of infected stems in any replication in any year.

${ }^{\mathrm{d}}$ Total number of replications tested, which may be the result of 1 to 4 years as an entry in the trial.

${ }^{\mathrm{e}}$ Calendar years in which a given genotype was assessed for SBWM incidence: $1=2000,2=2001,3$ $=2002$, and $4=2003$. 
Table 1. (continued from preceding page)

\begin{tabular}{|c|c|c|c|c|c|}
\hline Cultivar & $\begin{array}{c}\text { Average } \\
(\%)^{\mathrm{a}}\end{array}$ & $\begin{array}{l}\text { Min } \\
(\%)^{b}\end{array}$ & $\begin{array}{l}\text { Max } \\
(\%)^{c}\end{array}$ & $\begin{array}{c}\text { Sampled } \\
\text { rows }^{d}\end{array}$ & $\begin{array}{c}\text { Years } \\
\text { tested }^{\mathrm{e}}\end{array}$ \\
\hline U-1273-5-18-8 & 4.0 & 0.0 & 10.0 & 8 & $2,3,4$ \\
\hline Pearl & 3.9 & 0.0 & 15.0 & 11 & $1,2,3,4$ \\
\hline Foster & 3.8 & 0.0 & 10.0 & 11 & $1,2,3,4$ \\
\hline Pioneer 2510 & 3.6 & 0.0 & 20.0 & 11 & $1,2,3,4$ \\
\hline Patton & 3.5 & 0.0 & 23.3 & 11 & $1,2,3,4$ \\
\hline Whitby & 3.5 & 0.0 & 15.0 & 10 & $1,2,3,4$ \\
\hline NY92145BW-9144W & 3.3 & 0.0 & 10.0 & 3 & 4 \\
\hline TW97611 & 3.3 & 0.0 & 6.7 & 6 & 1,2 \\
\hline Elmira (Barley) & 2.9 & 0.0 & 10.0 & 8 & $2,3,4$ \\
\hline NY89086-7120 & 2.7 & 0.0 & 10.0 & 5 & 3,4 \\
\hline Hoffman 37 & 2.6 & 0.0 & 20.0 & 11 & $1,2,3,4$ \\
\hline Cayuga & 2.5 & 0.0 & 20.0 & 21 & $1,2,3,4$ \\
\hline NY90008-8092 & 2.5 & 0.0 & 5.0 & 4 & 3 \\
\hline TW96202 & 2.5 & 0.0 & 15.0 & 8 & $1,2,3$ \\
\hline NY89052-7142 & 2.3 & 0.0 & 5.0 & 5 & 3,4 \\
\hline NY89081-7161 & 2.3 & 0.0 & 6.7 & 5 & 3,4 \\
\hline Sawyer & 2.3 & 0.0 & 10.0 & 11 & $1,2,3,4$ \\
\hline CaledoniaResel-SS & 2.2 & 0.0 & 3.3 & 3 & 4 \\
\hline NY89056SP-9060 & 2.2 & 0.0 & 6.7 & 3 & 4 \\
\hline Pioneer 25R18 & 2.2 & 0.0 & 6.7 & 6 & 1,2 \\
\hline Pioneer 25R23 & 2.2 & 0.0 & 6.7 & 3 & 4 \\
\hline Pioneer 25R78 & 2.2 & 0.0 & 6.7 & 3 & 4 \\
\hline NY89052SP-9232 & 2.0 & 0.0 & 5.0 & 5 & 3,4 \\
\hline NY89056SP-7208 & 2.0 & 0.0 & 10.0 & 5 & 3,4 \\
\hline NY89064SP-7139 & 2.0 & 0.0 & 5.0 & 5 & 3,4 \\
\hline NY89066-7131 & 2.0 & 0.0 & 5.0 & 5 & 3,4 \\
\hline Houser & 1.7 & 0.0 & 10.0 & 11 & $1,2,3,4$ \\
\hline NY89052-9140 & 1.7 & 0.0 & 5.0 & 5 & 3,4 \\
\hline $\mathrm{T} 123$ & 1.7 & 0.0 & 5.0 & 5 & 3,4 \\
\hline Bavaria & 1.5 & 0.0 & 10.0 & 11 & $1,2,3,4$ \\
\hline Geneva & 1.3 & 0.0 & 13.3 & 22 & $1,2,3,4$ \\
\hline McGregor (barley) & 1.3 & 0.0 & 10.0 & 8 & $2,3,4$ \\
\hline NY89082-7159 & 1.3 & 0.0 & 6.7 & 5 & 3,4 \\
\hline A94-1315 & 1.2 & 0.0 & 5.0 & 11 & $1,2,3,4$ \\
\hline IL 91-15911 & 1.2 & 0.0 & 10.0 & 11 & $1,2,3,4$ \\
\hline KY86C-61-8 & 1.1 & 0.0 & 6.7 & 11 & $1,2,3,4$ \\
\hline NY88072-9070W & 1.1 & 0.0 & 3.3 & 3 & 4 \\
\hline NY91028SP-9245W & 1.1 & 0.0 & 3.3 & 3 & 4 \\
\hline NY93251R-9141W & 1.1 & 0.0 & 3.3 & 3 & 4 \\
\hline TW060-075 & 1.1 & 0.0 & 3.3 & 3 & 4 \\
\hline NY89014SP-9220 & 1.0 & 0.0 & 5.0 & 5 & 3,4 \\
\hline NY91017-8080 & 1.0 & 0.0 & 5.0 & 5 & 3,4 \\
\hline CaledoniaResel-S & 0.7 & 0.0 & 3.3 & 5 & 3,4 \\
\hline Century II & 0.6 & 0.0 & 3.3 & 6 & 1,2 \\
\hline Caledonia & 0.5 & 0.0 & 5.0 & 20 & $1,2,3,4$ \\
\hline Richland & 0.5 & 0.0 & 5.0 & 10 & 3,4 \\
\hline McDermott & 0.0 & 0.0 & 0.0 & 6 & 4 \\
\hline NY88041-9063W & 0.0 & 0.0 & 0.0 & 3 & 4 \\
\hline NY88046SP-9230W & 0.0 & 0.0 & 0.0 & 3 & 4 \\
\hline Red Caledonia & 0.0 & 0.0 & 0.0 & 3 & 4 \\
\hline Overall & 16.6 & 0.0 & 100.0 & 811 & $\ldots$ \\
\hline
\end{tabular}

(Table 1). Of the samples rated as symptomatic in the first year of the study, 97\% of the samples tested positive for SBWMV coat protein using ELISA. Nonsymptomatic plants were not tested for presence of SBWMV and, in subsequent years, we did not confirm our visual assessment with ELISA. Out of 28,270 stems assessed for soilborne virus symptoms in the SBWMV nursery in the 4 years of this study, only three stems had characteristic symptoms of the common soilborne virus Wheat spindle streak mosaic virus (WSSMV). These three stems tested positive for the presence of WSSMV by ELISA.

Below average disease incidence occurred in spring 2000 and 2001, with the average incidence across all genotypes being 4.6 and $9.6 \%$, respectively. The plot
SBWM incidence (Fig. 1, 2002 and 2003). Within our small nursery ( 30 by $15 \mathrm{~m}$ ), we observed a gradient of incidence for our susceptible check from 17.5 to $100 \%$ in 2002 and from 0.0 to $100 \%$ in 2003 .

Statistical analysis. Initially, only the last 2 years' data (2002 and 2003) were analyzed in order to understand how the disease gradient affected the results. A subset of 42 genotypes with at least 3 years' data was used to compare analyses from the first 2 years to the last 2 years. Analyzing ratio data (experimental genotype to nearest row of Harus) using a general linear model in SAS with Fisher's protected least significant difference for multiple comparisons analysis of squareroot (ratio) resulted in wide intervals of nonsignificance with only two discrete resistance classes, as defined in Materials and Methods (Table 2). Use of a logistic regression model, which recognizes each plant as an observation instead of each row, resulted in narrower intervals and increased from two to four the number of discrete resistance classes (Table 2). To incorporate our knowledge of disease gradients in the field, we added the number of symptomatic Harus plants in the nearest row as a covariate reflecting disease gradient. This additional information provided for a slightly better statistical model by decreasing the width of the intervals but did not alter the number of discrete resistance classes (Table 2).

In order to compare data between the 2 years with low disease incidence and the 2 years with high disease incidence, we used a logistic model containing year and genotype as predictors. In the years with low incidence, only three discrete resistance classes could be discerned, and only 12 of 42 genotypes were significantly more susceptible than the most resistant genotype, compared with 16 genotypes under high disease incidence in the last 2 years (Table 2). Thus, the first 2 years' data gave the false impression that four genotypes were resistant or moderately resistant. Analysis of all 4 years together resulted in four discrete resistance classes and 18 genotypes being significantly more susceptible than the most resistant genotype (Table 2).

To determine whether small sample size reduced the power of resistance assessment, we analyzed the first 2 years' results after extrapolating our data to sample sizes of 20 instead of 30 for three replications over each of 2 years. This analysis does not change the percent incidence or relative susceptibility, but did result in wider intervals of nonsignificance and reduced the number of disease resistance classes from three to two (Table 2). Furthermore, the smaller sample size resulted in three moderately susceptible genotypes being classified as resistant.

Choice of statistical method, accounting for disease gradient, low disease incidence, and extra years of repetition, affected the 

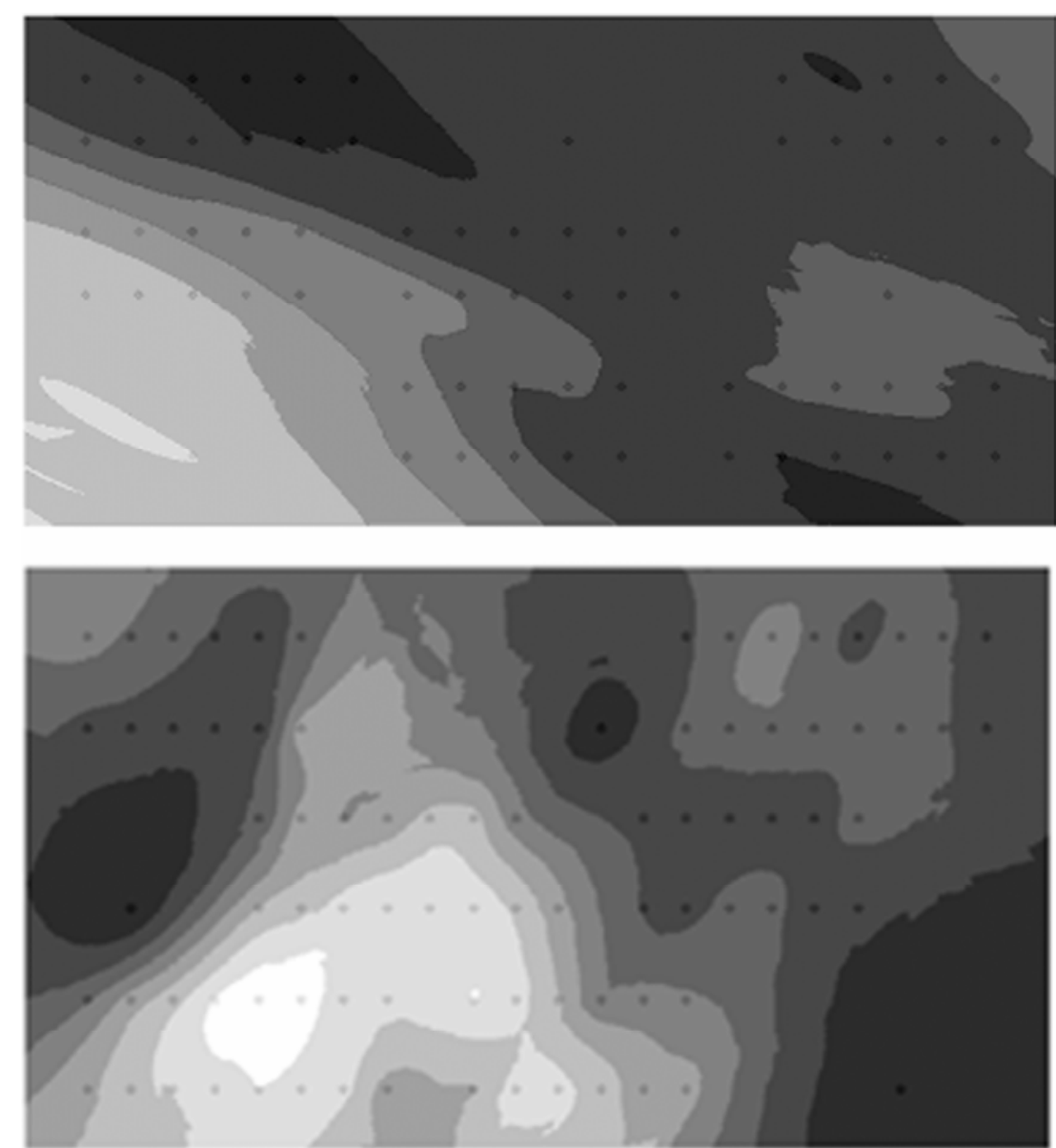

Interpolated SBWM incidence (\%)

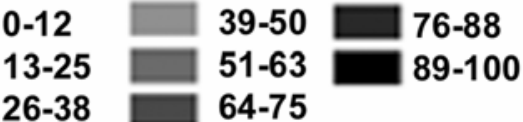

26-38 64-75

Fig. 1. Soilborne wheat mosaic virus (SBWM) distribution on 'Harus' wheat in spring 2002 (above) and 2003 (below). Point locations represent the middle of each row of the susceptible check Harus wheat, which was planted in every sixth row throughout the nursery. Location and corresponding incidence data were entered into a geographic information system and Kriging interpolation was performed. Shading represents a point estimate for the percent incidence of SBWM. Both maps are oriented with south at the top.

Table 2. Comparison of statistical models and data sets using the same subset of cultivars

\begin{tabular}{lccccc}
\hline Model $^{\mathbf{a}}$ & \multicolumn{2}{c}{ Years $^{\mathbf{b}}$} & No. of DRC $^{\mathbf{c}}$ & Average interval $^{\mathbf{d}}$ & No. susceptible $^{\mathbf{e}}$ \\
\hline GLM & $\ldots$ & 2002,2003 & 2 & 17.7 & 16 \\
Logistic & $\ldots$ & 2002,2003 & 4 & 13.4 & 16 \\
Logistic, covariate $^{\mathrm{f}}$ & $\ldots$ & 2002,2003 & 4 & 13.0 & 18 \\
Logistic & 2000,2001 & $\ldots$ & 3 & 15.2 & 12 \\
Logistic, $n=20^{\mathrm{g}}$ & 2000,2001 & $\ldots$ & 2 & 20.4 & 9 \\
Logistic & $2000,2001,2002,2003$ & 4 & 11.5 & 18 \\
\hline
\end{tabular}

a Statistical model used for analysis, either general linear model (GLM) or logistic model. In both cases, the predictors used were genotype and year unless otherwise noted.

b Year of the spring when incidence data was collected.

c Number of discrete resistance classes (DRCs), as described in the Materials and Methods.

d Average number of check cultivars not significantly different in soilborne wheat mosaic (SBWM) disease incidence than the test cultivar.

e Number of cultivars (out of 42) that had significantly higher SBWM disease incidence than the cultivar with the lowest SBWM disease incidence.

${ }^{\mathrm{f}}$ For this analysis, the incidence of SBWM on the closest row of 'Harus' wheat was used as a covariate in the statistical model.

g Data used in the analysis one line above was extrapolated from sample size of 30 to 20 and reanalyzed. relative ranks (Table 3 ). The risks of drawing conclusions from only 2 years of data also are revealed in Table 3. For example, 'Superior' and 'Roane' wheat were rated
Evaluating relative susceptibilities. Finally, we analyzed data from all 4 years for all genotypes using Proc Logistic (SAS) with the predictors 'year' and 'genotype' but not accounting for the disease gradient. The result suggests four significantly discrete resistance classes. Of the 115 genotypes tested, 41 were not significantly more susceptible than the most resistant check genotype, Caledonia (Fig. 2).

\section{DISCUSSION}

With SBWMV being recently introduced to Tompkins County, NY and spreading to surrounding counties, this study was essential for providing a control strategy for small grains producers in the region. We found that resistance is available in many cultivars adapted to the Northeast. These have been recommended to growers and adopted in areas at risk to infection by SBWMV. Cultivars should be tested in other locations or against other strains of SBWMV. The limited geographical infestation in New York probably is limited also in genetic diversity. Our data provide a large number of potential check cultivars for other environments.

This study also provided insights into the optimal conduct of field studies involving soilborne pathogens. Although the maps in Figure 1 reflect similar disease distributions in 2002 and 2003, their differences support the utility of a spatially balanced design, which increased the likelihood that multiple replications of all genotypes would encounter high disease pressure. The spatially balanced, randomized complete block design used in the final 2 years of the study was sufficient to account for the nonuniform disease distribution in our nursery. Statistical models that included disease distribution data provided no added benefit. However, when analyzing the logistic models with and without susceptible check cv. Harus as a covariate (Tables 1 and 2), the important point is interpreting which model could improve the accuracy of genotype classification where disease gradients confound the scoring. In this study, the two models led to the same conclusions about resistance of cultivars to SBWMV. Thus, we conclude that the simplest model is the best model in this case.

Different environments (years) changed not only the relative resistance ranks but also the number of cultivars in the highest resistance category. A previous study found that, in some years, in a subset of planting dates, resistant genotypes developed disease, resulting in significant genotype-planting date interactions (6). In the current study, moderately resistant cultivars appeared to be more resistant in years with low disease incidence. Given the spatial patchiness of virus or vector as well as the environmental sensitivity of transmission and symptom expression, reliable evaluation among the most resistant cultivars in the first 2 years of the study (under low disease pressure) but were rated among the more susceptible cultivars in the final 2 years. 
Table 3. Relative ranks of genotypes for data sets and analyses represented in Table 2

\begin{tabular}{|c|c|c|c|c|c|}
\hline \multirow[b]{2}{*}{ Genotype $^{a}$} & \multirow{2}{*}{$\begin{array}{c}\text { GLM } \\
2002-03^{b}\end{array}$} & \multicolumn{4}{|c|}{ Logistic } \\
\hline & & $2002-03^{c}$ & $2002-03$, covar. ${ }^{d}$ & $2000-01^{\mathrm{e}}$ & $2000-03^{f}$ \\
\hline Elmira (barley) & 6 & 6 & 6 & 23 & 10 \\
\hline McGregor (barley) & 6 & 6 & 6 & 19 & 3 \\
\hline Aroostock (rye) & 33 & 31 & 30 & 28 & 30 \\
\hline Presto (Tcl) & 30 & 32 & 33 & 34 & 33 \\
\hline RSI 815 (Tcl) & 17 & 16 & 9 & 23 & 16 \\
\hline RSI AZ 1998 (Tcl) & 29 & 28 & 27 & 39 & 34 \\
\hline RSIBG 1998 (Tcl) & 26 & 28 & 30 & 30 & 27 \\
\hline Trical $336(\mathrm{Tcl})$ & 35 & 30 & 27 & 40 & 35 \\
\hline Trical $815(\mathrm{Tcl})$ & 21 & 16 & 9 & 26 & 22 \\
\hline A94-1315 & 13 & 8 & 9 & 2 & 4 \\
\hline AC Ron & 27 & 27 & 29 & 20 & 26 \\
\hline Bavaria & 8 & 11 & 17 & 2 & 6 \\
\hline Caledonia & 1 & 1 & 3 & 1 & 1 \\
\hline Cardinal & 33 & 32 & 36 & 36 & 35 \\
\hline Cayuga & 8 & 11 & 9 & 2 & 10 \\
\hline Foster & 22 & 16 & 19 & 18 & 16 \\
\hline Freedom & 37 & 36 & 39 & 36 & 39 \\
\hline Geneva & 1 & 3 & 1 & 2 & 2 \\
\hline Harus & 40 & 36 & 37 & 35 & 38 \\
\hline Hoffman 37 & 13 & 15 & 15 & 2 & 10 \\
\hline Houser & 8 & 8 & 15 & 2 & 6 \\
\hline IL 91-15911 & 1 & 3 & 3 & 12 & 6 \\
\hline KY86C-61-8 & 1 & 3 & 3 & 12 & 4 \\
\hline Mendon & 30 & 32 & 32 & 27 & 29 \\
\hline NYBatavia & 19 & 19 & 24 & 12 & 23 \\
\hline OH 530 & 24 & 24 & 23 & 20 & 24 \\
\hline Patton & 13 & 19 & 19 & 12 & 16 \\
\hline Pearl & 19 & 19 & 22 & 2 & 16 \\
\hline Pioneer 2510 & 23 & 19 & 19 & 2 & 13 \\
\hline Pioneer 2540 & 8 & 14 & 6 & 31 & 27 \\
\hline Pioneer 2548 & 35 & 35 & 34 & 32 & 32 \\
\hline Pioneer 25R37 & 1 & 3 & 1 & 33 & 16 \\
\hline Pioneer 25W33 & 30 & 38 & 35 & 22 & 31 \\
\hline Roane & 27 & 26 & 25 & 2 & 25 \\
\hline Sawyer & 13 & 8 & 9 & 12 & 9 \\
\hline Sisson & 38 & 38 & 38 & 42 & 42 \\
\hline Superior & 25 & 25 & 26 & 2 & 21 \\
\hline TW97613 & 42 & 42 & 42 & 36 & 40 \\
\hline U-1273-5-18-8 & 8 & 11 & 9 & 25 & 13 \\
\hline Va $96 W-247$ & 40 & 40 & 40 & 41 & 40 \\
\hline Watford & 38 & 41 & 41 & 28 & 35 \\
\hline Whitby & 17 & 19 & 17 & 17 & 13 \\
\hline
\end{tabular}

all genotypes are wheat unless otherwise noted; $\mathrm{Tcl}=$ triticale.

${ }^{\mathrm{b}}$ Relative resistance ranking (1 to 42 , most resistant to most susceptible) resulting from analyzing genotype:Harus data as a general linear model (GLM).

c Relative resistance ranking resulting from analyzing a logistic model without accounting for disease gradient, using the last 2 years' data.

${ }^{\mathrm{d}}$ Relative resistance ranking resulting from analyzing a logistic model while accounting for disease gradient with Harus as a covariate, using the last 2 years' data

e Relative resistance ranking resulting from analyzing a logistic model without accounting for disease gradient, using the first 2 years' data.

${ }^{\mathrm{f}}$ Relative resistance ranking resulting from analyzing a logistic model without accounting for disease gradient, using all 4 years' data.

of resistance requires compilation of multiple years of replicated data.

In field trials, sampling time often is compromised by weather or lack of resources, and researchers are forced to sample fewer individuals or fewer replicates. This was the case in spring 2002, when there was capacity to assess only two replications of 20 individuals $(n=20$, rep $=2$ ). In order to visualize the effect of this constraint, we reanalyzed the first 2 years of data $(n=30$, rep $=3)$ after extrapolating the same percentages to smaller sample sizes but retained all three replications $(n=$ 20 , rep $=3$ ). The results, shown in Tables 1 and 2 , reflect but underestimate the loss of power using the smaller sample size in
2002. Of course, the sample size required is dependent upon the variance of disease incidence, but the sample size of 30 was significantly better than 20 for assessing SBWMV incidence data in this study.

Figure 2 may be interpreted to reflect four discrete clusters of response to SBWMV. These response clusters may have a quantitative genetic basis consistent with published findings that resistance in individual cultivars is conditioned by one to three genes $(4,14,15,17,18,20)$. Although the current study was not designed to investigate the inheritance of resistance, the objective and quantitative nature of the method developed could be particularly useful in such studies.

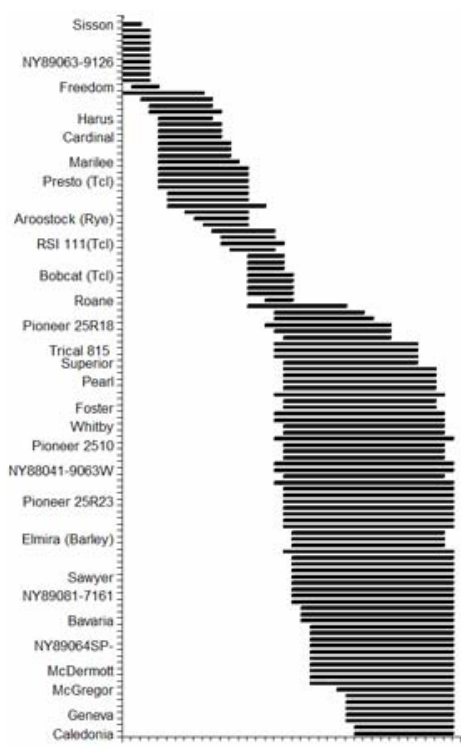

Fig. 2. Relative resistance of 115 small grains genotypes to Soilborne wheat mosaic virus (SBWMV) based on disease incidence. Each horizontal bar is the confidence interval for disease incidence of one $y$-axis genotype relative to disease incidence of $x$-axis genotypes. The $y$-axis represents the entire set of 115 genotypes assessed for resistance to SBWMV and sorted from most susceptible (top) to most resistant (bottom). For readability, only 29 genotypes of interest are labeled. The $\mathrm{x}$-axis represents 38 check genotypes sorted from most susceptible (left) to most resistant (right). Genotypes on the $y$-axis with overlapping bars did not have significantly different percent incidences of SBWM over the course of the study, relative to the check cultivars represented on the $\mathrm{x}$-axis.

\section{ACKNOWLEDGMENTS}

This research was supported by Cornell University Hatch Projects NYC153472, NYC153433, and NYC149419; a grant from the New York State IPM Program; a fellowship to L. Cadle-Davidson from the Storkan-Hanes-McCaslin Research Foundation; and a graduate research assistantship to L. CadleDavidson from the Department of Plant Pathology, Cornell University, Ithaca, NY. The plots were expertly aligned, planted, and managed by $\mathrm{D}$. Benscher and D. Valenta.

\section{LITERATURE CITED}

1. Adams, M. J. 1990. Epidemiology of fungallytransmitted viruses. Soil Use Manage. 6:184189.

2. Adams, M. J., Jones, P., and Swaby, A. G. 1987. The effect of cultivar used as host for Polymyxa graminis on the multiplication and transmission of Barley yellow mosaic virus (BaYMV). Ann. Appl. Biol. 110:321-327.

3. Adams, M. J., Swaby, A. G., and Macfarlane, I. 1986. The susceptibility of barley cultivars to Barley yellow mosaic virus (BaYMV) and its fungal vector, Polymyxa graminis. Ann. Appl. Biol. 109:561-572.

4. Barbosa, M. M., Goulart, L. R., Prestes, A. M., and Juliatti, F. C. 2001. Genetic control of resistance to Soilborne wheat mosaic virus in Brazilian cultivars of Triticum aestivum L. Thell. Euphytica 122:417-422.

5. Bockus, W. W., and Niblett, C. L. 1984. A procedure to identify resistance to Wheat soilborne mosaic in wheat seedlings. Plant Dis. 68:123-124.

6. Cadle-Davidson, L., and Bergstrom, G. C 2004. The effects of post-planting environment on the incidence of soilborne viruses of small 
grains. Phytopathology 94:527-534.

7. Cadle-Davidson, L., Schindelbeck, R. R., van Es, H. M., Gray, S. M., and Bergstrom, G. C. 2003. Using air pressure cells to evaluate the effect of soil environment on the transmission of soilborne viruses of wheat. Phytopathology 93:1131-1136.

8. Cadle-Davidson, L., Sorrells, M. E., Gray, S. M., and Bergstrom, G. C. 2006. Identification of small grains genotypes resistant to Wheat spindle streak mosaic virus. Plant Dis. 90:1045-1050

9. Goovaerts, P. 1992. Factorial Kriging analysis-a useful tool for exploring the structure of multivariate spatial soil information. J. Soil Sci. 43:597-619.

10. Himmel, P. T., Hewings, A. D., and Glawe, D. A. 1991. Incidence of Soilborne wheat mosaic virus and its reported vector Polymyxa graminis in field-grown soft red winter wheat. Plant Dis. 75:1008-1012.

11. Hunger, R. M., Sherwood, J. L., Smith, E. L., and Armitage, C. R. 1991. Symptomatology and enzyme-linked immunosorbent assay used to facilitate breeding for resistance to Wheat soilborne mosaic. Crop Sci. 31:900-905.

12. Hunger, R. M., Verchot, J., Siegerist, W. C., Myers, L., and Payton, M. 1998. Effect of wheat soilborne mosaic on yield and quality of grain from wheat. (Abstr.) Phytopathology 88:S42.

13. McKinney, H. H. 1925. A mosaic disease of winter wheat and winter rye. United States Department of Agriculture, Washington, D.C.

14. Merkle, O. G., and Smith, E. L. 1983. Inheritance of resistance to Soilborne mosaic in wheat. Crop Sci. 23:1075-1076.

15. Myake, N. 1939. Mendellian inheritance of resistance to mosaic disease in wheat varieties. Plant Breed. Abstr. 9:300.

16. Myers, L. D., Sherwood, J. L., Siegerist, W. C., and Hunger, R. M. 1993. Temperatureinfluenced virus movement in expression of resistance to Soilborne wheat mosaic virus in hard red winter wheat (Triticum aestivum). Phytopathology 83:548-551.

17. Nakagawa, M., Soga, Y., Okasima, N., Yoshioka, A., and Nisimata, D. 1959. Genetic stud- ies on the wheat mosaic virus. I. Genes controlling the manifestation of green mosaic virus in wheat. Plant Breed. Abstr. 29:739.

18. Nakagawa, M., Soga, Y., Watanabe, S., Gocho, H., and Nishio, K. 1960. Genetic studies on the wheat mosaic virus. II. Genes controlling the manifestation of yellow mosaic virus in wheat. Plant Breed. Abstr. 30:508.

19. Pennington, R. E., Sherwood, J. L., and Hunger, R. M. 1993. A PCR-based assay for Wheat soilborne mosaic virus in hard red winter wheat. Plant Dis. 77:1202-1205.

20. Shaalan, M. I., Heyne, E. G., and Sill, W. H., Jr. 1966. Breeding wheat for resistance to Soilborne wheat mosaic virus, Wheat streakmosaic virus, leaf rust, stem rust, and bunt. Phytopathology 56:664-668.

21. Williams, E., and Young, H. C. Wheat soilborne mosaic virus disease. Oklahoma State University, Stillwater.

22. Yili, R., Zou, W. H., and Chen, J. P. 1990. Quantitative assay of resting spores of Polymyxa graminis on barley roots. Ann. Appl. Biol. 117:343-347. 